\title{
English in ASEAN: Implications for Regional Multilingualism
}

\author{
Andy Kirkpatrick \\ Griffith University, Queensland, Australia
}

\begin{abstract}
The Charter of the Association of Southeast Asian Nations (ASEAN) was officially adopted in February 2009. Article 34 of the Charter states that, 'The working language of ASEAN shall be English'. In this article, I shall first briefly trace the development of English in ASEAN and demonstrate that, even in those countries of the ASEAN group, which were not colonies of Britain or the United States, English has become increasingly important. I shall show that, in almost all cases, the language policies of ASEAN countries require people to learn their respective national language and English. This combination of the learning of English is along with the national language, which can be a national lingua franca such as Bahasa Indonesia in Indonesia and Filipino in the Philippines. As a consequence, local and indigenous languages, other than the national language, are being replaced by English in many school curricula and in other domains. It is also rare to find government schools in ASEAN teaching the national languages of other ASEAN states. I shall conclude by considering the implications of this for multilingualism in the region.
\end{abstract}

Keywords: English and multilingualism; language education; Southeast Asia

\section{Introduction}

The Association of Southeast Asian Nations (ASEAN) was first formed in 1967 with the signing of the Bangkok Declaration. It was founded at a time of political uncertainty when many people feared that communism would sweep the region. For example, the war in Vietnam was raging at the time. ASEAN originally comprised only five countries: Indonesia, Malaysia, the Philippines, Singapore and Thailand. Since then, ASEAN has grown to include five further countries of Southeast Asia, namely, with the year of their joining ASEAN in brackets: Brunei (1984); Vietnam (1995); Laos and Myanmar (1997); and, finally, Cambodia (1999). Surprisingly, the Bangkok Declaration of 1967 made no mention of languages at all. Apparently, delegates simply assumed that English would be the common language, despite the fact that some form of Malay was an official language in three of the five founding member states (Indonesia, Malaysia and Singapore) and spoken by some people in the other two (Okudaira 1999:95).

Thus English became the de facto lingua franca of ASEAN (Krasnick 1995). It was not until the signing of the ASEAN Charter in 2009, however, that this de facto use of English became officially sanctioned. Article 34 of the Charter states that, "The working language of ASEAN shall be English'. And, although Article 2 of the Charter lists, as one of its principles, 'respect for the different languages of the peoples of ASEAN' there is no mention of a regional language or language education policy through which this respect for the different languages might be realized (Kirkpatrick 2010:7). As I shall argue below, the privileging of English as the sole official working language of ASEAN, along with the promotion in education of the respective national languages, means that the future of many of the more than a thousand languages spoken within ASEAN is likely to be under 
threat. In the next sections of this article, the respective roles of English and Asian languages in the school curricula of each of the ten countries will be briefly summarized.

First, the situation in the countries, which were once colonies of English speaking nations, will be considered. Following Kachru (1985), I shall refer to these as the 'outer circle' countries. Then the situation in those countries which were either colonies of other nations or which were never colonized will be presented. Again, following Kachru, these will be referred to as the 'expanding circle' countries, though, like Feng (this volume) we shall argue that the term expanding circle needs radical revision to account for the extraordinary increase in the use of English in these countries. Finally the implications of this for multilingualism in the region will be discussed.

\section{The 'Outer Circle’ Countries: Brunei, Malaysia, Myanmar, the Philippines, Singapore}

Brunei, Malaysia, Myanmar, and Singapore were all colonies of Britain. The Philippines was a colony of the United States. As a result, English has retained special status in all these countries (with the exception of Myanmar, as will be explained later) and this has lead to the development of specific varieties of English, such as Singaporean English (e.g., Platt and Weber 1981) and Filipino English (e. g., Bautista 1997). While there have been many changes in the language education policies over the years, in the Philippines and Brunei, English is currently used as the medium of instruction for mathematics and science subjects from the first year of primary school. In Singapore, English is the medium of instruction for all subjects. In Malaysia, English has been the medium of instruction for mathematics and science since 2002, although the government has recently announced that mathematics and science will revert to being taught through the national language, Malay, from 2012. In Myanmar, English is taught as a subject in primary schools.

The use of English as a medium of instruction for mathematics and science from primary 1 in these contexts has met with almost universal criticism by education scholars, who argue that children need to learn complex subjects though their first language in the early years, wherever possible (e.g., Benson 2008, Kosonen and Young 2009, Coleman 2010). An example from the Philippines may help to make clear just how cognitively and linguistically challenging that country's Bilingual Education Policy (BEP) is for many Filipino children. The BEP, which was first implemented in 1974, requires children to learn mathematics and science through English from Primary 1 and other subjects through Filipino. It needs to be stressed that Filipino is itself something of an artificial construct, as it is actually based on Tagalog, the language spoken in and around the capital Manila. That is to say, Filipino is not the first language of the great majority of Filipinos. Indeed it can be the third language that a Filipino child learns. For example, children who live in the Cebuano speaking region are likely to speak a local language as their mother tongue and the regional lingua franca, Cebuano, as their second language. This means that when they go to school, they have to learn in what may be two new languages. As Kosonen has pointed out, while the BEP lists English and Filipino as the languages of education and literacy, 'the majority of Filipinos do not speak either of these two languages as their mother tongue' (2009:31).

Language education policy is complex in multilingual societies. In the context of the Philippines, where more than 100 languages are spoken, Maminto (2005:335-7) raises a 
number of important questions, which are paraphrased below (see also Kirkpatrick 2010:40):

As four languages can be involved how can the curriculum be managed to ensure students learn successfully?

How can languages develop a complementary rather than competitive relationship?

When should the regional / national language take over or work alongside the mother tongue?

When should English be introduced and how?

These questions can be applied to virtually every country in ASEAN and I shall address them in a general way in the concluding section of this article. Here it can be noted that the Philippine Department of Education announced a radical change of policy in 2009 when it issued the order Institutionalizing Mother Tongue-based Multilingual Education (http://mothertongue-based.blogspot.com) which recognizes the importance of using the learner's mother tongue as the medium of instruction in the early years of primary school. But while the order asks for it to be implemented immediately, it is yet to be seen how effectively and widespread the implementation will be. However, in 2010, the Department of Education organized the first conference-workshop on mother tongue-based multilingual education, so there appears to be a genuine desire to see mother tongue-based education introduced. Pilot projects in the use of two indigenous languages, Lubuguan (Walker and Dekker 2008) and Minanubu, as media of instruction, have shown encouraging results 'so it is important that the use of the mother tongue as a medium of instruction in the first two grades be sustained' (Qijano and Eustaquio 2009: $160)$. It is to be hoped that these pilot projects lead to more programmes which promote local languages as the medium of instruction, for, at the moment, success for a Filipino child depends greatly on being born into a middle-class Tagalog (Filipino) speaking family in Manila (Bautista1996:225), as these children are likely to speak both Filipino and English.

The Malaysian Government is also currently supporting more mother tongue education in that it is increasing the role of Malay as a medium of instruction. After experimenting for several years with English as the medium of instruction for mathematics and science from Primary 1, schools will revert to the use of Malay for these subjects from 2012. This decision was taken as exam results showed that children from poorer and rural backgrounds were failing to cope with learning science and mathematics through English. A correspondent in the New Straits Times newspaper of 21 March 2009 put the question bluntly:

'They (the students) can't even understand English, how can you make them study Science and Math in English?'

There was also a serious shortage of mathematics and science teachers who were able to teach these subjects through English. The decision, however, has not been popular with the urban middle class, who see proficiency in English as a critical skill for 
obtaining good jobs and providing upward social mobility for their children, and who believe that the earlier children learn English the more proficient they will become. But, as has been consistently pointed out by language education specialists, English language teaching in the early years of primary school is frequently unsuccessful for a number of reasons. There is a severe shortage of suitably qualified and linguistically proficient English teachers. English plays little or no role in the lives of the children outside school. There are no appropriate materials (Martin 2010). And, perhaps most importantly, English replaces another subject - almost always a local language - in the curriculum. Coleman goes as far to say that the early teaching of English 'does not help children in their educational careers and it may actually be counterproductive' (2010:3).

With regard to the teaching of other languages in Malaysian schools, so-called 'national-type' schools acknowledge the presence of substantial numbers of Chinese and Indian Malaysians and such schools can choose to use either Mandarin Chinese or Tamil as media of instruction. And while government policy is for the pupil's own language to be taught as a subject if there is a minimum of 15 students and if there are teachers who can teach it and materials through which to teach it, in effect only three indigenous languages are taught. These are Semai in Peninsula Malaysia, Iban in Sarawak and Kadazandusun in Sabah. However, these programmes are not without problems. For example, in Sabah, 'educated parents talk to their children in English rather than in their mother tongue' (Logijin 2009:154), as they regard English as the language of academia and prestige. In Sarawak, even though Kadazandusun is taught in as many as 279 primary schools, it is taught after hours, outside the normal school timetable. There is also a shortage of qualified teachers and materials (Logijin 2009:157).

Perhaps inevitably, given the history of language education in both countries, Brunei has, in contrast to Malaysia, increased the amount of English as a medium of instruction in the primary school. In 2009, The Brunei Government adopted the National Education System for the 21 $1^{\text {st }}$ Century (SPN 21) (http://www.moe.edu.bn/web/spn21). This will make English the medium of instruction for both mathematics and science from Primary 1. This represents a significant change to the long-established bilingual (dwibahasa) policy whereby Malay was used as the medium of instruction for the first three years of primary (Jones 2000). English only became the medium of instruction for mathematics, science, history, geography and technical subjects from Primary 4. Malay remained the medium of instruction for other subjects including Malay literature, handicrafts, and Islamic knowledge.

In one sense, the dwibahasa policy could be described as being a great success, as many of Brunei's younger generation are speaking Malay as their first language so a Bruneian 'could now be defined as a Malay-English bilingual' (Jones 2009:59). However, none of the indigenous languages of Brunei (Belait, Bisaya, Dusun, Kedayan, Murut, Iban or Kelabit) are being maintained and thus have a bleak future (Noor Azam 2005). As I shall suggest in the conclusion, this shift to bilingualism in the national language and English that can be seen in Brunei is being repeated across ASEAN and this is endangering many of the region's local languages.

The country in ASEAN which has privileged English the most is Singapore. It is the medium of instruction. Other languages are taught only as subjects and these are officially restricted to three so-called 'mother tongue' languages, namely Mandarin Chinese, Malay and Tamil. This means that Singapore's bilingual policy aims at ensuring Singaporean citizens learn English plus a mother tongue. It needs to be underlined, 
however, that the 'mother tongue' languages on offer are not necessarily the learners' mother tongues. In the case of Mandarin, for example, it is possible that another Chinese language is spoken at home, even though the government has proscribed the use of Chinese languages other than Mandarin in official contexts, including education. Indians, however, can learn Indian languages other than Tamil, but the local community is responsible for the teaching of these languages (Tan 2007). It is also increasingly likely that English is, in fact, the main language of the home. Figures spanning the years 20002005 show that the percentage of respondents indicating that English is their home language has increased across the board, while the percentage of those indicating that Tamil, Malay or a Chinese dialect is their home language has decreased. The percentage of ethnic Chinese indicating that Mandarin is their home language increased slightly over this period from $45.1 \%$ to $47.2 \%$ (Tupas 2011:60). As Pang points out, since the 2000 census, 'there has been an increase in the use of English as the predominant home language among all the major ethnic groups', and that 'English is emerging as the language of the young' (2009:93-94). These figures suggest that the government's hope that its people would learn English for international communication and a mother tongue for their cultural roots is not being fulfilled. In fact, Singapore English has become the marker of Singaporean identity. The government has recently recognized that the bilingual policy has not been the success it had hoped for and called for a review of the teaching of the four languages, English, Mandarin, Malay and Tamil. There was particular concern that the overall level in Chinese was declining, especially in terms of literacy in Chinese and in the depth of knowledge of Chinese culture (Goh 2009). The Temasek Review of 18 November 2009 (Temasek Review 2009) reported the Minister Mentor, Lee Kwan Yew had admitted the bilingual policy and the way that Chinese had been taught was a mistake.

We started the wrong way. We insisted on ting xie (listening), mo xie (dictation) madness! We had teachers who were teaching in completely Chinese schools. And they did not want to use any English to teach English-speaking children Chinese and that turned them off completely.

Lee Kwan Yew's remarks here are noteworthy for a number of reasons. First they show that many Singaporeans who are ethnically Chinese are English speaking. Second they support the notion of a bilingual pedagogy in the classroom - in this case the use of English in the teaching of Chinese - and this represents a significant change from the traditional view that only the target language should be used in the language classroom. The remarks also reflect just how much curriculum time is needed in order for children to gain a working literacy of Chinese. It has been estimated that children take two years longer to become literate in Chinese than in an alphabetic language like English (Chen 1999:143). In addition, the extra curriculum time spent on acquiring literacy, along with the amount of homework in practising writing Chinese characters that children are given, need to be taken into account. In this, while Hong Kong is not part of ASEAN, the Hong Kong government's continued insistence that Cantonese be the medium of instruction in government primary schools appears far-sighted, as that not only allows children to learn in their mother tongue, but also ensures they develop literacy in Chinese. 
The final 'outer circle' country to be considered here is Myanmar. Unlike the other outer circle countries, however, its long-term 'closed door' policy has meant that English has long since ceased to have any institutional role. It is difficult to get reliable figures for the number of languages spoken in Myanmar - estimates vary between seventy to over a hundred (Watkins 2007). It is also difficult to get information about which languages are taught in schools. While the 1974 constitution allowed mother tonguebased education, the recent 2008 constitution makes no mention of language education or languages of education (Kosonen 2009). Interestingly, Burmese has become the lingua franca of the country, as opposition groups now use Burmese when dealing with the government. For example, 'Karen tribesman can only co-ordinate their resistance to the Myanmar government through the use of Burmese' (Ostler 2009:194). The Myanmar government has therefore promoted the use of minority languages, but more in an attempt to divide the opposition than in any attempt to revivify indigenous languages (Callahan 2003:166).

In this section I have briefly reviewed language education and language education policies in the five 'outer circle' countries of ASEAN. Even though it could be argued that English continues to play a major role in four of these five countries because of a shared colonial heritage, it can also be argued that the importance attached to English has, generally speaking, increased since these countries achieved their independence. The reasons for this are largely instrumental. People see English as essential for modernization and internationalization. An added localized motivation for learning English is the fact that it has been officially enshrined as the sole working language of ASEAN. As we shall see in the following section, these motivations to learn English are also operating in the remaining five countries of ASEAN.

The Expanding Circle Countries: Cambodia, Indonesia, Laos, Thailand, Vietnam. In Kachru's original formulation, the Expanding Circle 'includes the regions where the performance varieties of the language are used essentially in EFL (English as a Foreign Language) contexts' (1985:367). As indicated earlier, this assessment now needs to be reconsidered because, as will become clear, English is playing an increasingly important role in each of these countries. It is no longer only used in English as a Foreign Language context, but rather as a major medium of communication or lingua franca between the countries. As will be seen, English is now also taught as the first foreign language in each of the countries and often as a medium of instruction.

Indonesia is the largest and most diverse country in ASEAN. It has a population of some 220 million comprising more than 200 ethnic groups speaking more than seven hundred languages (Hadisantosa 2010). Before independence, it was a colony, but of the Netherlands. The 1945 constitution established Bahasa Indonesia (BI) as the national language. This was an interesting choice as a national language and needs a brief explanation. The language of most speakers in Indonesia is Javanese with 75 million speakers. Yet Javanese was not adopted as the national language for two main reasons. First, it was thought that this would further privilege the most powerful group in the country. Second, the language, Javanese, is characterized by its myriad politeness markers and respect forms (Bernard 2003). The newly independent Indonesians wanted a more 'democratic' language as their national language. Malay, the basis for Bahasa Indonesia, seemed an ideal choice. First it was only spoken by a very small percentage of the population and therefore provided no immediate advantage to an already powerful 
group. Second, it was considered easier to learn than Javanese. Its adoption as the national language met without resistance.

It appears that the selection of the Malay language as the Indonesian national language was quite smooth...there has never been any opposition to the language (Montolalu and Suryadinata 2007:41).

Given that only a mere $3 \%$ of the population spoke the language as a mother tongue when it was adopted as the national language, its success is remarkable. The table below (adapted from Montolalu and Suryadinata 2007:48) shows that, by 2000, $34 \%$ of the population claimed to speak BI as a first language.

Table 1: Vernacular language speakers in 1980, 1990, 2000

\begin{tabular}{|l|c|c|c|}
\hline \multicolumn{1}{|c|}{ Language } & $\mathbf{1 9 8 0}$ & $\mathbf{1 9 9 0}$ & $\mathbf{2 0 0 0}$ \\
\hline Javanese & $40.44 \%$ & $38.08 \%$ & $34.70 \%$ \\
\hline Sundanese & $15.06 \%$ & $15.26 \%$ & $13.86 \%$ \\
\hline Madurese & $4.71 \%$ & $4.29 \%$ & $3.78 \%$ \\
\hline Batak & $2.12 \%$ & $1.97 \%$ & $1.91 \%$ \\
\hline Minangkabau & $2.42 \%$ & $2.23 \%$ & $2.06 \%$ \\
\hline Balinese & $1.69 \%$ & $1.64 \%$ & $1.42 \%$ \\
\hline Buginese & $2.26 \%$ & $2.04 \%$ & $1.91 \%$ \\
\hline Indonesian $(\mathrm{BI})$ & $11.93 \%$ & $17.11 \%$ & $34.00 \%$ \\
\hline Others & $17.48 \%$ & $17.11 \%$ & $4.57 \%$ \\
\hline
\end{tabular}

The table also shows that the percentage of people reporting that they are mother tongue speakers of other languages has dropped slightly over the period, but with the greatest drop being seen in the 'others' column, where the percentage of mother tongue speakers has declined from $17.48 \%$ in 1980 to less than 5\% in 2000. This suggests that $\mathrm{BI}$ is growing at the expense of the other languages. The percentage of those claiming to speak BI is also impressive. Maryanto (2009:72) claims that, by the late $1990 \mathrm{~s}, 83 \%$ of the population spoke BI, but it is not clear what 'speaking Indonesian' actually means. Nevertheless, by any measure, the uptake of $\mathrm{BI}$ as a national language and lingua franca is impressive.

Indonesia is also noteworthy in being the only country of ASEAN that has not made English a compulsory part of the primary curriculum, although a primary school that did not offer English would be unlikely to attract many students. Indonesia has also recently introduced the concept of sekolah bertaraf internasional (SBIs) or international standard schools. These are supposed to introduce English as a medium of instruction for mathematics and science from Primary 4, but many teach these subjects through English from earlier grades. As mentioned earlier, the introduction of English into the primary curriculum almost always means that a local language is dropped. As one critic of these new SBI schools observes: 
"...with (the) emerging and mushrooming demand for English, schools then drop the local language in order to give more time to the English teaching. As a result, in the long run, children and the younger generation can no longer speak the local language. This is culturally and linguistically pitiful" (Hadisantosa 2010: 31).

Again, the trends of bilingualism being realized as the national language and English along with the decline of other local languages can be seen to be developing in Indonesia. These trends can also be observed in the three countries, which shared a history of being under French colonial rule, Cambodia, Laos and Vietnam.

The Vietnamese Government has routinely promoted multilingual education and supported the development of writing systems for those indigenous languages that are without orthographies so that, today, some thirty of the officially recognized fifty four indigenous languages now have these (Kosonen 2009:36). But even though the use of mother tongues is supported in policy, 'Vietnamese remains, in practice, the main language of instruction at all levels of education' (2009:37). It is also important to note that the policy of promoting minority languages in Vietnam has the ultimate aim of assimilating the minorities (Le and O'Harrow 2007:436). Children are encouraged to become literate in their first languages so that they can then be taught Vietnamese more easily.

The decision of the Vietnamese government to open up the country to the world in 1986 led to a feverish demand for English:

When Vietnam embarked on economic reforms in 1986...it promoted a nationwide rush to learn English...English classes were crammed with not just students but also professionals such as doctors and engineers and well as retired government officials, senior police, army officers and diplomats (cited in Ho and Wong 2004:1).

This demand for English is reflected in the fact that $90 \%$ of children are now learning English. Demand for French, the 'colonial' language, has fallen dramatically. English is by far the most popular foreign language and is introduced from Primary 3. Despite the relative success of pilot projects where Khmer, Hmong and J'rai are taught alongside Vietnamese, the great majority of Vietnamese are learning Vietnamese and English. Vietnam's joining of ASEAN in 1995, is just one motivation for this. In a major new initiative, 'English 2020', Vietnam aims to get all college graduates able to use English by the end of the next decade. Some indication of the ambitious nature of this project is that it will require the retraining of more than 60,000 English language teachers (Hung, Hoa and Dudzik 2011).

English has also replaced French as the foreign language of highest demand in Cambodia. It is taught from Primary 5 for between 2-5 hours a week. Like Vietnam, Cambodia is also relatively linguistically homogenous with some $90 \%$ of the population being Khmer speakers. The Cambodian government also promotes some bilingual programmes for speakers of indigenous languages (Thomas 2002). Bilingual pedagogy is also encouraged in certain areas where 'teachers may conduct some instruction of the class in the minority language, and may translate key vocabulary items contained in textbooks from Khmer to the minority language as a means of assisting student learning' (Neou Sun 2009: 65). However, again as with Vietnam, the main aim of developing 
literacy among the minorities appears to be for them to become assimilated by becoming literate in the national language, Khmer.

Cambodia's development from an 'expanding circle' country to one where English is important within the country is evidenced by the fact that English is needed for work in all foreign agencies. Cambodia's membership of ASEAN has also promoted the demand for English, as these comments from government officials illustrate:

If we don't know English, how can we participate?

We need to know English so that we can defend our interests. You know, ASEAN is not a kissy-kissy brotherhood. The countries are fiercely competitive, and a strong knowledge of English will help us protect Cambodian interests (cited in Clayton 2006:230-231).

These comments along with others reported by Clayton such as, 'You know, when we use English, we don't think about the United States or England. We only think about the need to communicate' (2006:233) has led Clayton to refer to Cambodia as a setting where the use of English is not post-colonial but post-Anglophone. That is to say, the major role of English is not to communicate with Anglophones, but with fellow multilinguals who have themselves learned English as an additional language. In this sense, we can refer to ASEAN as a post-Anglophone setting. Far from reducing the demand for English, however, this post-Anglophone role greatly increases it.

Laos is more linguistically heterogeneous than either Vietnam or Cambodia. The official division of the Lao people into Lowland Lao, Midland Lao and Upland Lao is artificial as, not only do they speak different languages, the languages they speak are from different language families (Watkins 2007). The Lowland Lai speak Tai languages, the Midland Lao speak Mon-Khmer and the Upland Lao speak Tibeto-Burman languages. So, while Lao itself - a member of the Tai family of languages - acts as a lingua franca, it is not a marker of national identity (Keyes 2003). One estimate has less than $50 \%$ of the population speaking Lao as a first language (Kosonen 2009). Lao is also viewed with some suspicion by minority ethnic groups such as the Hmong. Reliable information concerning the teaching and maintenance of minority languages remains hard to obtain as 'there are no explicit policies relating to the use of non-dominant languages in education (Kosonen 2009:28). Nevertheless, some small pilot bilingual projects are being planned.

Despite Laos' French heritage, English has now become the first foreign language and is introduced from Primary 3, despite a lack of suitably qualified and proficient English teachers (Phommanimith 2008).

The final country to be considered is Thailand, the only country of the ten that has never been colonized. The great majority of Thais - some fifty million out of a total population of sixty million - classify themselves as speakers of Thai (Luangthongkum 2007). However, more than sixty other languages are spoken albeit by less than $5 \%$ of the population. The dominant role of standard Thai in education and the, by now, familiar and typical emergence of English as the first foreign language taught in schools, means that these languages are under threat. Two quotes from scholars of Thai language education policy help underline this trend. In a study of language use in an Isan village in northeast Thailand, Draper reports that Isan speakers are shifting to the use of Thai. 
'Significant shift is occurring in the direction of CT (Central Thai) as a result of mass media and central government policies' (Draper 2010:136). This is despite a reported Isan desire for multilingual education. The overall picture is summarized succinctly by Prapasapong. 'Local languages are losing their significance in Thai society' (2009:107).

These two sections have shown that, despite the diversity within and between each of the ten countries of ASEAN, the same linguistic trends can be detected. These are that each nation is promoting the use of the national language along with English, often at the expense of local languages and the use of multilingual mother tongue education. It is, however, extremely difficult to obtain precise or reliable figures concerning the actual number of endangered languages in the region. For example, for Southeast Asia, the number of endangered languages varies from 145 to 171 (Bradley 2001).

In the concluding section below, I consider the possible implications of this and suggest an alternative to the current national language plus English bilingual model of language education in schools.

\section{Implications and a Way Forward}

The ten countries of ASEAN currently represent great linguistic diversity with more than a thousand languages from a range of different language families spoken throughout the region (Kirkpatrick 2010). However, the desire for each of the ten nations to establish a national language - and the general overall success in doing this - together with the need to use English as a language of modernisation and international communication, has seriously diminished interest in and the promotion of local languages. There might, however, be a place for some local languages in education were not English being adopted as the second language of education. The fact that English is also now being introduced as a compulsory subject into the primary curriculum in all ten countries with the exception of Indonesia adds to the threat for local languages, as English almost always replaces a local language in the primary curriculum. And, as Coleman points out, 'A very effective way of killing a language is to deny it any place in the education system' (2010:17). One reason for this is that parents naturally want what they perceive to be the best for their children, and will therefore marginalize a home language, even within the home itself, if it is not part of the education system.

We have seen that not only is English introduced early into the primary curriculum in most countries, it is also used as a medium of instruction in several. The reasons for this are presumably because governments and parents hold to three tenets of language learning, namely:

(i) The best way to learn a language is to use it a as medium of instruction;

(ii) To learn a second language you must start as early as possible;

(iii) the home language gets in the way of learning a second language (Benson 2008)

Benson (2008:3 ff) has eloquently demonstrated that these three tenets are, in fact, myths. Kosonen has termed the use of what is to the learner a foreign language as a medium of instruction as 'submersion education', defined as 'the deployment of a language of instruction that the learner does not speak or understand' (2009:13). With 
specific reference to the teaching and learning of mathematics and science, the Filipino scholar Bernardo (2000:313) has demonstrated that:

There are clear and consistent advantages to using the student's first language ....at the stages of learning where the student is acquiring the basic understanding of the various mathematical concepts and procedures.

Some thirty years ago, Cummins (1981) showed that a child typically needs at least five years' of second language learning before it can be successfully used as a medium of instruction. All the evidence shows that children are advantaged by learning in their mother tongue in the early years of schooling; and will be seriously disadvantaged if forced to learn subjects though a language that neither speak nor understand.

The argument here is not that content subjects cannot be successfully learned through a foreign language. There are many examples that have shown that immersion programmes in which the students learn through a foreign language can be successful. The Canadian immersion programme is one such example (Swain and Johnston 1997). The argument rather, is that children need to have a firm grounding in the foreign language in order to be able to learn complex concepts through it. This is particularly the case when the languages involved are not from the same language family, as is the case throughout ASEAN, when English is introduced as a medium of instruction from the early years of primary school.

With regard to the second tenet/myth listed above, in certain circumstances this may well be true. Cenoz reports that research in 'natural language environments' supports the notion of 'the earlier the better' (2009:189). However, we need to note that Cenoz is referring to 'natural language environments'. The great majority of learners of English in ASEAN primary schools are not learning in natural language environments. On the contrary, they are typically learning in contexts where the teachers are not adequately proficient in the language, where there are insufficient and inappropriate materials, and where English has little, if any, role to play outside the classroom. I argue, therefore, that it would be far better if their first language replaced English as a language of education in the primary school.

This brings us to the third tenet/myth listed above. Far from getting in the way of learning a second language, all the research shows that the home language acts as a bridge to second language learning (Benson 2008). Children are able to transfer the skills they have developed while learning their first language to second language learning (Cummins 2008). Thus, not only would children be advantaged in the learning of content subjects in their mother tongue, they would also be advantaged for later second language learning if the mother tongue was a language of school education.

If the ideas above were adopted it would mean that the ASEAN primary school would focus on the learning of the mother tongue and the national language. In highly multilingual settings where the use of the mother tongue as a language of education would be impractical, the regional lingua franca could be used instead. Thus, a primary school in the Cebuano speaking region of the Philippines would teach in Cebuano and Filipino, but Cebuano should be the medium of instruction for at least the first three years of primary school. English can be introduced as a subject in the later years of primary. 
However, I would argue that it could be more effective and efficient to delay the introduction of English until the secondary school, and allow the primary school to focus on the local and national language. Delaying the teaching of English until secondary school can offer a number of advantages. To name just three: it is more likely that suitably qualified and proficient teachers can be found; appropriate materials can be developed; and the children will be cognitively mature and able to transfer the skills they have acquired in learning local languages to the learning of English and thus learn it far more quickly than if they had started before they were ready. Perhaps most importantly, however, it would also help increase primary school retention rates, as children would be learning in their home and familiar languages. The UNESCO report Education for All by 2015 (UNESCO 2007) identifies the language of mother tongue multilingual education as a fundamental cause of primary drop out rates in many of the countries of ASEAN (Kirkpatrick 2010:160).

Adopting a language education policy that could be simply summarized as 'primary for local, secondary for English', would, I believe, provide a win-win result for all. First, at least some local languages would be maintained and strengthened, as they would become languages of education. Second, children would learn their respective national languages and become bilingual in Asian languages and, given that many more children would now learn in their mother tongues, primary retention rates would increase. Third, more children would become trilingual, with English as their third language. If, however, the current language education policy of teaching only the national language + English is retained, then the future Asian multilingual is likely to be bilingual only in the national language and English.

\section{References}

Bautista, Ma. Lourdes. 1996. Outline: The national language and the language of instruction. In Readings in Philippine Sociolinguistics, ed Ma. Lourdes Bautista, 223-227. Manila: De la Salle University Press.

Bautista, Ma. Lourdes ed. 1997. English is an Asian language: The Philippine context. Sydney: The Macquarie Library.

Benson, C. 2008. Summary overview. Mother tongue-based education in multi-lingual contexts. In Improving the quality of mother tongue-based literacy and learning. Case studies from Asia, Africa and South America ed. C. Haddad, 2-11. Bangkok: UNESCO.

Bernard, J. 2003. Language policy and the promotion of national identity in Indonesia. In Fighting words: language policy and ethnic relations in Asia, ed. M. Brown and S. Ganguly, 263-290. Cambridge, MA: MIT Press.

Bernardo, Allan B.I. 2000. The multifarious effects of language on mathematical learning and performance among bilingual: a cognitive science perspective. In In Parangalcang Brother Andrew: a festschrift for Andrew Gonzalez on his sixtieth birthday, ed. Ma Lourdes Bautista, T. A. Llamzon and B. P. Sibayan, 303-316. Manila: Linguistic Society of the Philippines.

Bradley, David. 2011. A survey of language endangerment. In The handbook of endangered languages, ed by P. Austin and J. Sallabank, 66-77, Cambridge: Cambridge University Press. 
Callahan, Mary P. 2003. Language policy in modern Burma. In Fighting words: language policy and ethnic relations in Asia, ed. M. Brown and S. Ganguly, 143-175. Cambridge, MA: MIT Press.

Cenoz, Jasone. 2009. Towards multilingual education. Bristol: Multilingual Matters.

Chen, Ping. 1999. Modern Chinese: history and sociolinguistics. Cambridge: Cambridge University Press.

Clayton, Thomas. 2006. Language choice in a nation under transition: English language spread in Cambodia. Boston, MA: Springer.

Coleman, H. 2010. Teaching and learning in Pakistan: the role of language in education. Islamabad: The British Council.

Cummins, Jim. 1981. Age on arrival and second language learning in Canada: A reassessment. Applied Linguistics, 1: 132-149.

Cummins, Jim. 2008. Teaching for transfer: Challenging the two solitudes assumption in bilingual education. The Encyclopedia of Language and Education. Vol. 5. Bilingual Education, 65-75. New York: Springer.

Draper, J.C. 2010. Inferring ethnolinguistic vitality in a community of Northeast Thailand. Journal of Multilingual and Multicultural Development 31, no. 2:135-147.

Goh Yeng Seng. 2009. Bilingual education policy in Singapore: challenges and opportunities. In Language Teaching in a Multilingual World, ed. Chris Ward, 171190. Singapore: SEAMEO Regional Language Centre (RELC).

Hadisantosa, Nilawati. 2010. Insights from Indonesia. In Learning through English: policies, challenges and prospects, ed. Richard Johnstone, 24-46. London: British Council.

Ho, Wah Kam and Wong, Ruth Y.L. (eds.) 2004. English language teaching in East Asia today. Singapore: Eastern Universities Press.

Hung, Ngyuen Ngo, Hoa, Nguyen and Dudzki D. L. 2011. Policy, preparation, practice: Vietnam's English 2020 initiatives. Paper presented at the TESOL Convention, March 16-19, New Orleans.

Jones, Gary M. 2000. Some language planning questions facing Brunei Darussalam, Singapore, Malaysia and the Philippines. In Parangalcang Brother Andrew: A festschrift for Andrew Gonzalez on his sixtieth birthday, ed. by Ma. Lourdes Bautista, T. A. Llamzon, and B. P. Sibayan, 226-238. Manila: Linguistic Society of the Philippines, pp. 226-238.

Jones, Gary M. 2009. The evolution of language-in-education policies in Brunei Darussalam. In Mother tongue as bridge language of instruction: policies and experiences in Southeast Asia, ed. K. Kosonen and C. Young, 49-61.Bangkok: The Southeasst Asia Ministers of Education Organization.

Kachru, Braj B. 1985. Standards, codification and sociolinguistic realism: the English language in the outer circle. In English in the world, ed. R. Quirk and H. Widdowson, 11-30. Cambridge: Cambridge University Press.

Keyes, Charles F. 2003. The politics of language in Thailand and Laos. In Fighting Words: Language Policy and Ethnic Relations in Asia, ed. M. Brown and S. Ganguly, 177210. Cambridge MA: MIT Press.

Kirkpatrick, Andy. 2010. English as a lingua franca in ASEAN: a multilingual model. Hong Kong: Hong Kong University Press.

Kosonen, K. 2009. Language-in education policies in Southeast Asia: an overview. In Mother tongue as bridge language of instruction: policies and experiences in 
Southeast Asia, ed. K. Kosonen and C. Young, 22-41.Bangkok: The Southeast Asia Ministers of Education Organization.

Kosonen, K and Young, C. eds. 2009. Mother tongue as bridge language of instruction: policies and experiences in Southeast Asia. Bangkok: The Southeast Asia Ministers of Education Organization.

Krasnick, Harry. 1995. The role of linguaculture and intercultural communication in ASEAN in the year 2020: prospects and predictions. In Language and culture in multilingual societies, ed. M. Tickoo, 81-93. Singapore: SEAMEO Regional Language Centre.

Le, Minh-Hang and O'Harrow, Stephen. 2007. Vietnam. In Language and national identity in Asia, ed. A. Simpson, 415-441. Oxford: Oxford University Press.

Logijin S. 2009. A case study on the use of Kadazandusun in Malaysia. In Mother tongue as bridge language of instruction: policies and experiences in Southeast Asia, ed. K. Kosonen and C. Young, 153-158. Bangkok: The Southeast Asia Ministers of Education Organization.

Luangthongkum, Theraphan. 2007. The positions of non-Thai Languages in Thailand. In Language nation and development, ed. Lee Hock Guan and Leo Suryadinata, 181194. Singapore: Institute of Southeast Asian Studies.

Maminto, Rosario E. 2005. Program design and implementation of Philippine language education: research and theoretical perspectives. In Linguistics and language education in the Philippines and beyond: A Festschrift for Ma. Lourdes S. Bautista, ed. Danilo T. Dayag and J. Stephen Quakenbush, 335-348. Manila: Linguistic Society of the Philippines.

Martin, Isabel. 2010. Periphery ELT: the politics and practice of teaching English in the Philippines. In The Routledge Handbook of World Englishes, ed. A. Kirkpatrick, 247-264. London: Routledge.

Maryanto. 2009. Regional and local languages as languages of oral instruction in Indonesia. In Mother tongue as bridge language of instruction: policies and experiences in Southeast Asia, ed. K. Kosonen and C. Young, 69-75. Bangkok: The Southeast Asia Ministers of Education Organization.

Montolalu, Lucy R., and Suryadinata, Leo. 2007. National language and nation-building: The case of Bahasa Indonesia. In Language nation and development, ed. Lee Hock Guan and Leo Suryadinata, 39-50. Singapore: Institute of Southeast Asian Studies.

Neou Sun. 2009. Education policies for ethnic minorities in Cambodia. In Mother tongue as bridge language of instruction: policies and experiences in Southeast Asia, ed. K. Kosonen and C. Young, 62-68. Bangkok: The Southeast Asia Ministers of Education Organization.

Noor Azam. 2005. Changes in the linguistic diversity of Negara Brunei Darusssalam. PhD Thesis. University of Leicester

Okudaira, Akiko.1999. A study on international communication in regional organizations: the use of English as the "official" language of the Association of South East Asian Nations (ASEAN). Asian Englishes 2, no.1: 91-107.

Ostler, Nicholas. 2009. Review of Language and national identity in Asia. Language Policy, 8, no.2: 193-195.

Pang, E.S. 2009. Language and language-in-education policies and their implementation in Singapore In Mother tongue as bridge language of instruction: policies and 
experiences in Southeast Asia, ed. K. Kosonen and C. Young, 93-101. Bangkok: The Southeast Asia Ministers of Education Organization.

Platt, John, and Weber, Heidi. 1980. English in Singapore and Malaysia: status, features, functions. Kuala Lumpur: Oxford University Press.

Phommanimith, Khounmy. 2008. Country report on basic education curriculum in Lao PDR. Vientiane: Department of General Education, Ministry of Education.

Prapasapong B. 2009. Language policy and practice in public schools in Thailand. In Mother tongue as bridge language of instruction: policies and experiences in Southeast Asia, ed. K. Kosonen and C. Young, 102-108. Bangkok: The Southeast Asia Ministers of Education Organization.

Quijano Y.S. and Eustaquio O.H. 2009 Language-in-education policies and their implementation in Philippine public schools. In Mother tongue as bridge language of instruction: policies and experiences in Southeast Asia, ed. K. Kosonen and C. Young, 84-92. Bangkok: The Southeast Asia Ministers of Education Organization.

Swain, Merrill and Johnston, Keith. 1997. Immersion education: a category within bilingual education. In Immersion Education: International Perspectives, ed. M Swain and K Johnson, 1-16, Cambridge: Cambridge University Press.

Tan, Eugene B. 2007 Language policy and discourse in Singapore. In Language Nation and Development, ed. Lee Hock Guan and Leo Suryadinata, 74-117. Singapore: Institute of Southeast Asian Studies.

Temasek Review. 2009. MM Lee admits 'mistake' made in his education policy. http://www.temasekreview.com/2009/11/18/mm-lee-admits-mistake-made-inhis-education-policy/

Thomas, Anne. 2002. Bilingual community-based education in the Cambodian Highlands: a successful approach to enabling access to education by indigenous peoples. Journal of Southeast Asian Education, 3, no.1: 26-55.

Tupas, Ruanni. 2011. English knowing bilingualism in Singapore: economic pragmatics, ethnic relations and class In English Language Education Across Greater China, ed. Anwei Feng, 46-69. Bristol: Multilingual Matters.

UNESCO. 2007. Education for All by 2015. Will we make it? Oxford: Oxford University Press (http://unescdoc.unesco.org/images/0015/001547/15473e.pdf)

Walker, S. L. and Dekker, D. E. 2008. The Lubuagan Mother Tongue Education Experiment (FLC). A Report of Comparative Test Results. Summer Institute of Linguistics International.

Watkins, Justin. 2007. Burma/Myanmar. In Language and national identity in Asia, ed. A. Simpson, 263-287. Oxford: Oxford University Press. 